\title{
Population Dynamics of Predators and Parasitoids of Shoot and Fruit Borer, Earias spp in Okra Ecosystem
}

\author{
Sanjay Kumar ${ }^{1 *}$, Vimal Kumar Singh ${ }^{1}$, R.P. Singh ${ }^{1}$ and Arvind Kumar ${ }^{2}$ \\ ${ }^{1}$ Krishi Vigyan Kendra, Ujhani, Badaun (U.P.), India \\ ${ }^{2}$ Krishi Vigyan Kendra, Moradabad (U.P.), India \\ *Corresponding author
}

\section{A B S T R A C T}

\begin{tabular}{|c|}
\hline Keywords \\
\hline $\begin{array}{l}\text { Trichogramma spp, } \\
\text { Coccinellids, } \\
\text { Spider, Earias spp, } \\
\text { okra }\end{array}$ \\
\hline Article Info \\
\hline $\begin{array}{l}\text { Accepted: } \\
\text { 04 January } 2018 \\
\text { Available Online: } \\
\text { 10 February } 2018\end{array}$ \\
\hline
\end{tabular}

Keywords

Trichogramma spp,

Coccinellids,

Spider, Earias spp,

okra

Accepted:

04 January 2018

Available Online:

A field experiment was conducted during the Kharif seasons 2012 and 2013 at Students Instructional Farm and Vegetable Research Farm, NDUA\&T, Kumarganj, Faizabad (UP) to find out the natural enemies of shoot and fruit borer in okra. The eggs parasitoids Trichogramma chilonis, parasitized 6.25 and $7.40 \%$ egg of Earias spp Kharif, 2012 and Kharif, 2012 respectively. Among predators, maximum population of Coccinellids 4.36 and 4.05 adult per 5 plants was recorded in third week of August. The maximum population of spiders 6.40 and 6.22 individuals per 5 plant were in the last week of July, Ants population were 4.38 and 4.22 in the mid July of and Mirid bug ranged from 1.42 to 3.88 and 1.08 to 3.56 adult/ 5plant. The population of Coccinellids, spiders, ants and mirid bugs were positive correlated with minimum temperature i.e. $(0.921,0.809,0.777$ and $0.810)$ and $(0.595,0.407,0.347$ and 0.399$)$ respectively during Kharif, 2012 and 2013.

\section{Introduction}

Okra (Abelmoschus esculentus L. Moench.) is also known as Lady's finger, is a popular home garden vegetable in India and also cultivated in tropical and subtropical part of the world. It is a good source of vitamins, minerals, protein, fat, carbohydrate and has high caloric value. India has area under okra 511 thousand ha and production 5849 thousand MT during 2015-16. About 13 insect pests have been recorded that are known to cause damage to okra (Mandal et al., 2006). The shoot and fruit borers, Earias vittella is one of the major limiting factors in the production of quality fruits of okra (Kharbade et al., 1998). The infestation to okra accounted for nearly $22.5 \%$ in Uttar Pradesh (Verma et al., 1985), 25.9\% to 40.9\% in Madhya Pradesh by the shoot and fruit borer (Dhamdhare et al., 1984). Among natural enemies Spider, ants and Coccinellids are some that contributed to the reduction of insect pest of okra.

Keeping in view the importance of losses caused by different insect pests, the present study population dynamics of insect pests and its natural enemies were carried on okra. 


\section{Materials and Methods}

The experiment was conducted during the Kharif seasons 2012 and 2013 at Students Instructional Farm and Vegetable Research Farm, NDUA\&T, Kumarganj, Faizabad (UP).

The seed of okra (variety- Arka Anamika) was sown in the month of last week of June in both season and all the agronomic and cultural practices recommended for its cultivation were followed as per the requirement. The crop was sown in the plots of $4.5 \mathrm{~m} \mathrm{x} 3 \mathrm{~m}$ with row to row and plant to plant spacing 60 $\mathrm{cm} \times 45 \mathrm{~cm}$ respectively.

\section{Observations}

The eggs, larvae and pupa of okra shoot and fruit borer were collected along with their natural enemies from the experimental field and farmer's field at weekly interval and reared them in the laboratory in natural medium till the emergence of eggs, larval and pupal parasitoids.

The collected natural enemies were identified by taxonomic key and percentage of eggs, larval and pupal Parasitization were work out. The predators associated with the insect- pest of okra were recorded on five randomly selected plants at each replication and mean number of individual predator were calculated.

The data on meteorological parameters viz. temperature (minimum and maximum ${ }^{\circ} \mathrm{C}$ ), relative humidity $(\%)$, rain fall $(\mathrm{mm})$ and sunshine hours taken from the department of Agro Meteorology have been used to find out the correlation between natural enemies population with abiotic factors.

\section{Results and Discussion}

The natural enemies observed during experimentation are given in Table 1 .

\section{Parasitoids}

A total number of 112 and 135 eggs of shoot and fruit borers were collected but only 7 and 10 eggs were parasitized by the egg parasitoid, Trichogramma chilonis during both the seasons.

The egg parasitization was 6.25 and 7.40 per cent during Kharif, 2012 and Kharif, 2013 respectively.

\section{Predators}

The large numbers of predators were collected from the experimental field of okra were collected and placed in four groups i.e. coccinellids, spiders, ants and mirid bugs.

\section{Lady bird beetle}

The coccinellids i.e. (Coccinella septempunctata, Microspis discolor and Brumoides suturalis) were first appeared in the last week July (2.80 and 2.57 adult $/ 5$ plants) i.e. 31 Standard Week (SW) and there after continuously present throughout the crop season during Kharif, 2012 and 2013 respectively.

The maximum population of coccinellids (4.36 and 4.05 adult $/ 5$ plant) was recorded in third week of August ( $\left.34^{\text {th }} \mathrm{SW}\right)$ followed by (4.15 and 3.80 adult /5 plant), (3.93 and 3.72 adult $/ 5$ plant) in $33 \mathrm{rd}$ and $36^{\text {th }} \mathrm{SW}$, respectively and minimum was recorded (1.25 and 0.80 adult $/ 5$ plant) in $40^{\text {th }} \mathrm{SW}$ respectively during Kharif, 2012 and Kharif, 2013.

\section{Spiders}

The spiders were recorded throughout the crop season of okra and their population was ranged 2.88 to 6.40 and 2.51 to 6.22 individuals/ 5 plant during Kharif, 2012 and Kharif, 2013 respectively. 
Table.1 Population of predators in okra ecosystem during Kharif, 2012 and 2013

\begin{tabular}{|c|c|c|c|c|c|c|c|c|}
\hline \multirow{3}{*}{$\begin{array}{l}\text { Standard } \\
\text { Week }\end{array}$} & \multicolumn{8}{|c|}{ Mean number of Predators per five plants } \\
\hline & \multicolumn{2}{|c|}{ Coccinellids } & \multicolumn{2}{|c|}{ Spiders } & \multicolumn{2}{|c|}{ Ants } & \multicolumn{2}{|c|}{ Mirid bugs } \\
\hline & 2012 & 2013 & 2012 & 2013 & 2012 & 2013 & 2012 & 2013 \\
\hline 31 & 2.80 & 2.57 & 3.50 & 3.35 & 2.25 & 2.05 & 1.87 & 1.63 \\
\hline 32 & 3.38 & 3.15 & 4.30 & 3.80 & 2.80 & 2.66 & 2.40 & 2.25 \\
\hline 33 & 4.15 & 3.80 & 4.85 & 4.62 & 4.38 & 4.22 & 2.85 & 2.66 \\
\hline 34 & 4.36 & 4.05 & 6.20 & 5.88 & 3.80 & 3.56 & 3.60 & 3.25 \\
\hline 35 & 3.93 & 3.72 & 6.40 & 6.22 & 3.40 & 3.12 & 3.88 & 3.56 \\
\hline 36 & 3.65 & 3.35 & 5.12 & 4.66 & 2.75 & 2.50 & 2.82 & 2.64 \\
\hline 37 & 3.05 & 2.86 & 4.26 & 3.88 & 2.37 & 2.15 & 2.08 & 1.85 \\
\hline 38 & 2.70 & 2.54 & 3.55 & 3.37 & 2.05 & 1.86 & 1.66 & 1.40 \\
\hline 39 & 2.32 & 1.95 & 3.16 & 2.96 & 1.88 & 1.72 & 1.53 & 1.25 \\
\hline 40 & 1.25 & 0.80 & 2.88 & 2.51 & 1.67 & 1.35 & 1.42 & 1.08 \\
\hline Mean & 3.16 & 2.88 & 4.42 & 4.13 & 2.74 & 2.52 & 2.41 & 2.16 \\
\hline SEm \pm & 0.12 & 0.09 & 0.11 & 0.10 & 0.15 & 0.14 & 0.14 & 0.11 \\
\hline CD at $5 \%$ & 0.36 & 0.29 & 0.34 & 0.30 & 0.45 & 0.43 & 0.44 & 0.34 \\
\hline
\end{tabular}

Table.2 Correlation coefficient between natural enemies with abiotic factors in okra (Kharif, 2012 and 2013)

\begin{tabular}{|c|c|c|c|c|c|c|c|c|c|c|}
\hline \multirow{3}{*}{$\begin{array}{l}\text { Natural } \\
\text { Enemies }\end{array}$} & \multicolumn{4}{|c|}{ Temperature } & \multirow{2}{*}{\multicolumn{2}{|c|}{$\begin{array}{c}\text { Relative Humidity } \\
(\%)\end{array}$}} & \multirow{2}{*}{\multicolumn{2}{|c|}{$\begin{array}{l}\text { Rain fall } \\
\text { (mm) }\end{array}$}} & \multirow{2}{*}{\multicolumn{2}{|c|}{$\begin{array}{c}\text { Sunshine } \\
\text { (Hrs) }\end{array}$}} \\
\hline & & & & & & & & & & \\
\hline & Min. & Max. & Min. & Max. & 2012 & 2013 & 2012 & 2013 & 2012 & 2013 \\
\hline Coccinellids & $0.921 * *$ & -0.078 & 0.595 & 0.517 & $0.786 * *$ & -0.041 & 0.256 & -0.427 & -0.485 & 0.018 \\
\hline Spiders & $0.809 * *$ & -0.119 & 0.407 & 0.204 & $0.704 *$ & 0.295 & 0.134 & $-0.632 *$ & -0.354 & -0.395 \\
\hline Ants & $0.777 * *$ & 0.094 & 0.343 & 0.184 & 0.570 & 0.085 & 0.073 & -0.440 & -0.234 & -0.097 \\
\hline Mirid Bugs & $0.810 * *$ & -0.045 & 0.399 & 0.170 & $0.646^{*}$ & 0.266 & 0.075 & $-0.681 *$ & -0.273 & -0.389 \\
\hline
\end{tabular}


The maximum population of spider was recorded in $35^{\text {th }} \mathrm{SW}(6.40$ and 6.22 individuals/5plant) due to maximum host availability followed by $(6.20$ and 5.88 individuals/5plant), (5.12 and 4.66 individuals/5plant) at $34^{\text {th }}$ and $36^{\text {th }} \mathrm{SW}$. The minimum population was 2.88 and 2.51 in $40^{\text {th }}$ SW during Kharif, 2012 and Kharif, 2013 respectively.

\section{Ants}

The maximum number of black ants was noticed during the infestation of okra mealy bug because the ant feed on the honey dew secreted by the mealy bug and aphid. The ant was first time recorded at $31 \mathrm{SW}$ (2.25 to 2.05 adult/5 plant).

The population range 1.67 to 4.38 and 1.35 to 4.22 during Kharif, 2012 and Kharif, 2013 respectively. The maximum population of ant was recorded 4.38 and 4.22 in 33th SW followed by (3.80 and 3.56) in $34^{\text {th }} \mathrm{SW}$ and minimum in $40^{\text {th }} \mathrm{SW} 1.67$ and 1.35 adult/5 plants during Kharif, 2012 and Kharif,2013 respectively.

\section{Mirid bug}

The population of mirid bug ranged from 1.42 to 3.88 and 1.08 to 3.56 adult/ 5plant during Kharif 2012 and Kharif, 2013 respectively. The maximum population of mirid bug was recorded 3.88 and 3.56 in $35^{\text {th }} \mathrm{SW}$ followed by (3.60 and 3.25 adult/5plant), (2.88 and 2.66 adult $/ 5$ plant) in $34^{\text {th }}$ and $33^{\text {th }} \mathrm{SW}$ and minimum 1.42 and 1.08 adult $/ 5$ plant in $40^{\text {th }}$ SW during Kharif, 2012 and Kharif, 2013 respectively.

The result obtained on various natural enemies i.e., parasitoids and predators associated with the okra shoot and fruit borer during the respective years of the study is discussed as under (Table 2).

\section{Parasitoids}

The shoot and fruit borer's eggs parasitized by the egg parasitoid, Trichogramma chilonis during both the seasons. The egg parasitization was 6.25 and 7.40 per cent during Kharif, 2012 and Kharif, 2013 respectively. Maximum parasitization was recorded by egg parasitoid during Kharif, 2013. These finding collaborate with the studies of Telang et al., (2004) where the authors had noticed the $9.50 \%$ eggs of $E$. vittella parasitization by the Trichogramma chilonis. Yadav et al., (2009) reported 10 to 12 per cent parasitism of E. vittella eggs by Trichogramma chilonis.

\section{Predators}

The four groups of predators i.e. coccinellids, spider, ants and mirid bug were seen during crop season of okra. The population of lady bird beetle, coccinellids appeared first time in the last week of July (2.80 and 2.57 adult/ 5 plants) i.e. 31 Standard Week (SW) and that prevailed throughout the crop season during Kharif, 2012 and Kharif, 2013 respectively. The maximum population of coccinellids (4.36 and 4.05 adult /5 plant) was recorded in third week of August ( $\left.34^{\text {th }} \mathrm{SW}\right)$ followed by (4.15 and 3.80 adult /5 plant), (3.93 and 3.72 adult/5 plant) in 33rd and $36^{\text {th }} \mathrm{SW}$, respectively and minimum was recorded $(1.25$ and 0.80 adult $/ 5$ plant) in $40^{\text {th }} \mathrm{SW}$. The results of the present study are in conformity with the result of Mohanasundaram et al., (2012) who has reported that the coccinellids population was highest when okra was intercropped with cluster bean (4.6 and 4.3 individuals /5plants) and was on par intercropped with baby corn (4.6 and 4.1).

The spiders were present constantly throughout the crop season and their populations were higher in $35^{\text {th }} \mathrm{SW}$ (6.40 and 6.22 individuals/5plant) due to maximum host 
availability followed by $(6.20$ and 5.88 individuals $/ 5$ plant), (5.12 and 4.66 individuals $/ 5$ plant) at $34^{\text {th }}$ and $36^{\text {th }} \mathrm{SW}$. The minimum population was 2.88 and 2.51 in $40^{\text {th }}$ SW during Kharif 2012 and Kharif, 2013 respectively. On the basis of two years population, the spider judged as dominant predator.

The maximum number of black ants was noticed during the infestation of okra mealy bug because the ant feed on the honey dew secreted by mealy bug. The population of ants ranged 1.67 to 4.38 and 1.35 to 4.22 during Kharif, 2012 and 2013. The maximum population of ants was recorded 4.38 and 4.22 in 33th SW followed by (3.80 and 3.56) in $34^{\text {th }} \mathrm{SW}$ and minimum in $40^{\text {th }} \mathrm{SW}(1.67$ and 1.35 adult/5 plants) during Kharif, 2012 and Kharif, 2013 respectively.

The maximum population of mirid bugs was recorded 3.88 and 3.56 in $35^{\text {th }} \mathrm{SW}$ followed by (3.60 and 3.25 adult/5plant), (2.88 and 2.66 adult $/ 5$ plant) in $34^{\text {th }}$ and $33^{\text {th }} \mathrm{SW}$ and minimum 1.42 and 1.08 adult $/ 5$ plant in $40^{\text {th }}$ SW during Kharif, 2012 and 2013 respectively. The population of mirid bugs ranged from 1.42 to 3.88 and 1.08 to 3.56 adult/ 5plant during Kharif 2012 and Kharif, 2013 respectively.

\section{Correlation between predators with abiotic factors in okra}

The correlation coefficient of different predators i.e. Coccinellids, spiders, ants and mirid bugs with abiotic factors showed positive correlation with minimum temperature i.e. $\left(0.921^{* *}, 0.809^{* *}, 0.777^{* *}\right.$ and $\left.0.810^{* *}\right)$ and $(0.595,0.407,0.347$ and 0.399) respectively during Kharif, 2012 and Kharif, 2013. It was significantly correlated at 1\% level during Kharif, 2012 but nonsignificant during Kharif, 2013. The negative correlation was observed between the maximum temperature in coccinellids, spiders and mirid bugs i.e. $-0.078,-0.119$ and -0.045 but with ant the relation was positive (0.094) during Kharif, 2012 respectively. In Kharif 2013, the correlation with maximum temperature was positive with the predators. The relative humidity was positively correlated with the spiders $(0.704 * *$ and $0.295)$, ants (0.570 and 0.885$)$ and mirid bugs (0.646* and 0.266) during Kharif, 2012 and 2013, respectively but in coccinellids it was positive $\left(0.786^{* *}\right)$ in Kharif, 2012 and negative in Kharif, 2013. Rainfall was positively correlated with natural enemies (0.073 to 0.256) in Kharif, 2012 and significantly negative with spiders $(\mathrm{r}-0.632 *)$ and mirid bugs $\left(-0.681^{*}\right)$ at $5 \%$ level during Kharif, 2013. The sunshine was negatively correlated with the predators and varied (0.234 to -0.485$)$ and (-0.097 to-0.395) during Kharif, 2012 and Kharif, 2013 respectively. The result obtained on predatory population of shoot and fruit borer in okra during both Kharif season of study were similar to the finding of Mohanasundaram et al., (2012) and Sardana et al., (2005) who had reported that a large buildup of natural enemies viz, spiders and coccinellids were observed in unprotected crop module. Shinde et al., (2007) found that neem seed powder and NSKE 5\% recorded maximum population of lady bird beetles and spiders on okra. Abdalla (2012) reported that Chrysopids and spiders were the predominant predators in autumn and summer seasons, whereas syrphids, chrysopids and coccinellids were the abundant groups during winter. Singh et al., (2013) reported that the coccinellids showed negative correlation with minimum and maximum temperature, rain fall and relative humidity.

\section{Acknowledgements}

The authors are thankful to the Director of Research, Narendra Dev University of Agriculture and Technology, Kumargang, 
Faizabad and Head, Department of Entomology, College of Agriculture for the unstinted support and other research facilities provided to carry out the investigation.

\section{References}

Abdalla, A. Satti. 2012. The major predators and their seasonal abundance in okra fields at el-gorair scheme, Northern Sudan. The Experiment, 4 (4): 271-276.

Dhamdhere, S.V., Bahadur, J. and Mishra, U.S. 1984. Studies on occurance and succession of pest of okra at Gwalior. Indian J. Pl. Protection, 12(1): 9-12.

Kharbade, S.B., Chandel, A.G. and Dethe, M.D. 1998. Bioeffecacy of Bacillus thuringiensis (Berliner) varietal products against $E$. vittella (Fab.) on okra. Pestology, 22(11):8-10.

Mandal, S.K., Sah, S.B. and Gupta, S.C. 2006a. Efficacy and economics of biopesticide and insecticide combinations against okra pests. International J. Agric. Sci. 2(2): 377380.

Mohanasundaram, A; Sharma, R.K and Sharma, K. 2012. Eco-friendly management of major insect pests of okra with intercropping and newer molecules. Indian J. Plant Protection, 40(1): 32- 37.
Sardana, H.R., Bambawale, O.M., Kadu, L.N. and Singh, D.K. 2005. Development and validation of adaptable IPM in okra through farmers' participatory approach. Ann. Plant Protection Sciences, 13(1):54-59.

Shinde, S.R., Singh, R. and Sharma, R. K. 2007. Management of Insect pests of okra through insecticides and intercropping. Ann. Pl. Protection Sci., 15(2): 321-324.

Singh, Y., Jha, A., Verma, S., Mishra, V. K. and Singh, S. S. 2013. Population dynamics of sucking insect pests and its natural enemies on okra agro-ecosystem in Chitrakoot region. African $J$. Agricultural Research, 8(28): 38143819.

Telang, S.M., Rathod, K.S. and Rathod, R.M. 2004. Parasitization by different parasites of E. vittella in okra. J. Soils and Crops, 14 (2): 335-339.

Verma, G. S. 1985. Response of chemicals to control spotted bollworm in okra. Indian J. Entomology, 47(3): 357-358.

Yadav, J.B., Singh, R.S., Singh, H.P. and Singh, A.K. 2009. Effect of abiotic and biotic factors on jassid and fruit and shoot borer in Kharif, okra Crop. International J. Plant Protection, 2(1): 119-122.

\section{How to cite this article:}

Sanjay Kumar, Vimal Kumar Singh, R.P. Singh and Arvind Kumar. 2018. Population Dynamics of Predators and Parasitoids of Shoot and Fruit Borer, Earias spp in Okra Ecosystem. Int.J.Curr.Microbiol.App.Sci. 7(02): 210-215. doi: https://doi.org/10.20546/ijcmas.2018.702.026 